\title{
The Dilemmas of Change Higher Education in Belarus
}

\section{James L. Bess}

James L. Bess is professor of Hgher Education af New York University. Address Program in Higher Education, East Building, 239 Greene St. New York University, NY, NY, 10003. Fox-212-995-404 I

$\mathrm{L}$ ike most of the countries in the former Soviet Union, for higher education as well as its internal conditionspresent difficult problems to those who see a need for a transformation of colleges and universities to meet the ideological and practical needs of a democratic and free-enterprise system. In the following,some of those problems are described.

Before the dissolution of the Soviet Union, educational policy was created in and directed from Moscow, with the "GOS-PLAN" determining both the numbers of students to be trained in over 7,000specializations and their placement after graduation in positions throughout the USSR. While the centralized planning system resulted in egregious under- or overproduction of specialists because of unanticipated time lags in both the education and employment sectors, it did ensure the development both of a highly efficient system of higher education and a superbly educated work force with a high certainty of employment in their specializations. The system's goals, however, were narrowly illiberal and vocationally focused. Today, absent centralized planning from Moscow and without a job market for its college graduates, colleges and universities in Belarus nevertheless continue to produce technologically skilled and knowledgeableworkers, a large number of whom cannot be placed in jobs within the boundaries of the country. Further, the narrowness of the subject matters taught, the didactic form of the pedagogy, and the propagandistic underpinning of the curriculum render graduates so rigidly fixed in their self-images that they are unable to imagine alternative futures either for themselves or the society as a whole, and they cannot adapt to individual circumstances or opportunities even when available.

While it might seem that the institutionalizahon of a market-driven, rather than centrally planned, system of educational training would be propitious in Belarus, the issue of educational standards (as well as simple inertia) inhibits such a move. Proud of their educational system and of the knowledge of their college graduates, and highly anxious to ensure that their quondam teaching competencies will continue to he utilized, faculty and administrators in Belarus, as well as officials in the Ministry of Education, press to preserve their status, structure, and roles by argu- ing that a "deterioration of standards" will ensue if some centralized control over quality is not maintained. The dissolution of the Soviet Union brought about enormous social, political, and cultural upheaval in all of its former political units, including Belarus, so such a grasping at the straws of educational tradition is understandable.

The following is a list of five external forces inhibiting changes in higher education.

\section{Changes in Culture and Values}

Despite its strong residual belief in Marxist philosophy as the appropriate underpinning of its system of higher education, the citizens of Belarus are aware of the legacy of many years of Soviet repression, subversion, secrecy, and political privilege, and the peremptory loss to the state of earned or acquired personal property. The result is an paralyzing ambivalencetoward government. On the one hand, because the people have been so long dependent on it for almost all initiatives and have been socialized into believing in its probity and good intentions, most citizens have a suspicion of ideas (and the people who hold them) that differ from the prevailing centrally promulgated doctrines. On the other hand, the failure of the state since political independence in 1991 to provide the promised utopia or even a modicum of the good life results in an overall disenchantment with centrally mandated ideas (as well as an almost overwhelmingand deepening pessimism and malaise).

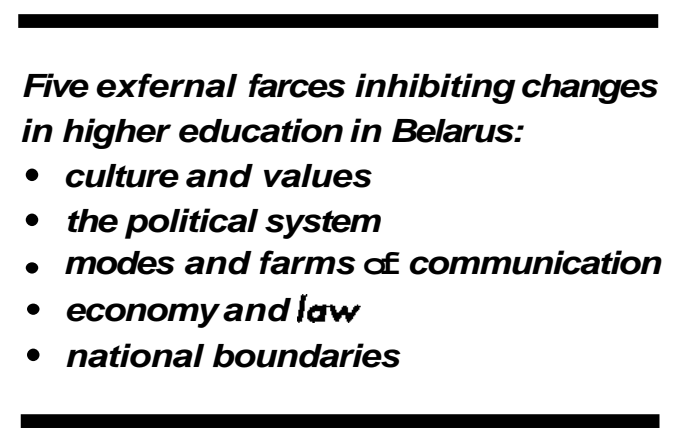

The present social system is thus virtually anomic, with an unfocused new competing rather unsuccessfully with the jaded old for salience. The impact on higher education of the allegiance to cultural preservation, however, is significant. The privileged few, among both faculty and administrators, fight to maintain their status; the vast majority are simply resigned to the worst or hopeful that they will be rescued by an outside force-Russia, in particular. Disenchanted and discouraged students go through the motions of education, then stand in line after graduation for scarce choice positions, much as their parents wait, mostly in vain, for political and economic salvation. 


\section{Changes in the Political System}

Most Belarussians are without knowledge of how a democraticsystem works and, partly as a result, are skeptical that it can work. The current political climate is both uncertain and volatile. Strong-arm tactics by incumbents to ensure political reinstatement are widely reported. The recent parliamentary elections have put in place a leadership that is conservative and committed to the past, both internally and in relationships with other governments - again, especially Russia. Higher education does little to develop a citizenrythat can create, maintain, and legitimize a democratic ethos or apparatus (e.g., an "opposition party").

\section{Changes in Modes and Forms of Communication}

Despite the presence of some $\mathbf{2 2 0}$ newspapers in Belarus (13 1 in the Belarussian language), for all intents and purposes, there is no truly "free" press, and the major modem method of communication, television, is completely controlled by the government. Indeed, two of the three television stations that broadcast to Belarus emanate in Moscow. Newspapers have very small circulations and are usually both uninformed about political events and uncaring about them. Dissent and real political debate in the media are absent. Colleges and universities, often centers of free speech and academic freedom in the West, are, in Belarus, without serious dissenters and do not produce graduates who are knowledgeable about or inclined to use a free press to generate a new society.

\section{Cbanges in Economy and Law}

Economies in transition confront many and varied challenges, but the foremost among them is the stabilization of the macroeconomicsystem. This includesreducing the role that government plays in microeconomic decisions and privatization. Moving from a system with complete centralized control over the planning and execution of the economy to one that is market-driven, loosely structured, and somewhat out of control is again an idea that is mysterious and frightening to most Belarussians. The state is still the largest (indeed, virtually the only) employerin the country, with more than two-thirds of all employees working in state-owned enterprises, another $\mathbf{2 0}$ percent in collective farms, and 9 percent working in businesses leased by the state.

Most Belarussians would like to become part of the middle or upper class, but resent those who display the accouterments of newly gained financial success (in too obvious violation of Marxian egalitarianism). Private property, both homes and goods, is still an idea that is not meaningful to most Belarussians. The privatization of the former collective farms has, with few exceptions, not taken place, and even when it has, it is clear that farmers do not know how to manage their limited independence.

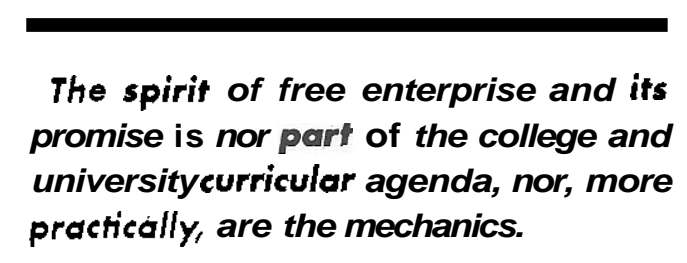

The promise of the economic future of Belarus appears ambiguous. Most Belarussians do not see the present manifestations of progress (e.g., the kiosks and the folding beds that serve as display tables for imported domestic goods in open markets) as the beginnings of a new, improved mode of economic commerce with fantastic potential for "the good life," but as free enterprise itself for all that it can be. The current failed incremental capitalism is thus far a poor incentive for personal initiative. The legal system, too, is totally inadequate to manage the conditions of a free enterprise system with private property as well as a democratic societywith concomitant issues of individual rights.

Unfortunately, higher education, once again, offers little to remedy these deficiencies. The spirit of free enterprise and its promise is not part of the college and university curricular agenda, nor, more practically, are the mechanics.

\section{National Boundaries}

Belarus is virtually closed to outside influence, save for American films and black market goods. The unwillingness of the government to open the boundaries to foreign ideas and capitalist investment is understandable, but illadvised. Both knowledge and expertise about democracy and capitalism are needed - and quickly. Unfortunately, cross-boundary excursions abroad by Belarussian faculty and students are currently economically out of reach, as is the importation of foreign faculty who would displace or augment native faculty. A recent idealistic attempt at the ministry level to create internationally known centers of educational excellence ("capitalizing," for example, on Belarus's extraordinary experience and knowledge in some fields of physics) has promise but will take many years to implement.

\section{Change}

The processes of building an educational system that will prepare Belarussians for a different social system will require many decades. There are many levers that need to be pushed for change in higher education to take place in 
Belarus. Among the most important:

1. A shift in the planning and evaluation mechanism from a stiff, centralized control at the ministry to a more decentralized, faculty/professionally dominated one, with local or at least regionally based partial power of compromise and implementation.

2. A national faculty development program designed both to educate faculty as to new educational objectives, alternative modes of teaching, and new career paths. Faculty seem at the heart of the change process in Belarus. If the country is to develop into a democracy and free enterprise state, students must be enabled to grow and develop as unique individuals, not as tools of the state. The curriculum and extracurriculum must change accordingly. Moving from an objective of transmission of known truths through didactic means to an open, inquiring, questioning perspective will require much adjustment - and considerable faculty development. In the United States, new models of education are now finding their way into the design of institutions. These new models suggest that students must learn to develop a sense of self-identity, become more expressive, better able to relate to others, more willing to take risks, etc. To accomplish these ends in Belarus, new forms of instruction are necessary. Equally important, new forms ofinstitutionalized out-of-class activities must he set up to augment and support the classroominstruction. Further, the curriculum must shift from an emphasis on science and engineering to one favoring the preparation of students for entrepreneurial activity and business occupations.

3. A strengthening of the private higher education sector. Diversity is a prerequisite for change, since it breeds divergent thinking. Any country so dominated by a state system as Belarus will have difficulty encouraging innovation and change. There must be encouragement and support for private postsecondary education. The support may take many forms, including state financial aid to students for attendance at private institutions. The private system cannot he merely "parallel" or "peripheral," as in France and Sweden, hut instead, a significant and energizing force in the educational system. The very competition for students among the private institutions symbolizes a democratic/ capitalist system that should mirror the larger economic system for the country as a whole.

\section{Developing a Canadian Science and Technology Strategy}

\section{Glen A. Jones}

Glen A. Jones is Associate Professor, Higher Education Group, Ontario Institutefor Studies in Education, 252 Bloor Street West, Toronto, Ontario, CANADA Fax: 416-926-4725 E-Mail: giones@oje.on.ca

$\mathrm{C}$ anada has never really had a broad, national science and technology policy. While the federal government is the largest single source of support for university research, the vast majority of the government's activities in the area of science and technology has evolved from a diverse range of initiativesinvolving a wide range of federal departments and programs. A variety of departments operate research facilities or directly or indirectly support research activities, but, like many aspects of Canadian government activity, the approach has tended to be more sectoral and regional rather than national and comprehensive.

A national review of science and technology was initiated shortly after the election of a Liberal government in 1993, and led to the creation of a National Advisory Board on Science and Technology (NABST). The public consultation process involved the development of a series of background documents that provided a foundation for 25 community workshops, 5 regional conferences, and a national conference held in Ottawa at the end of 1994. Nineteen prominent individuals from industry, education, and research were appointed to the NABST, and their final report was released in April 1995.
The two external components of the review have served to highlight a number of important issues and questions concerning Canada's science and technology activities. While the federal government's expenditure on research and development as a percentage of GDP is roughly comparable with other nations in the Organisation for Economic Co-operation and Development (OECD) (though slightly lower), expenditures by industry are significantly lower than almost all of Canada's industrialized peers.

The final report of the NABST, entitled Healtby Wealtby and Wise,' notes that the federal government is now the "single largest performer" of science and technology in Canada. While the government spends approximately $\$ 980$ million supporting research performed by industry, and $\$ 950$ million supporting research performed by universities, over $\mathbf{\$ 3 , 4 0 0 m i l l i o n ~ i s ~ s p e n t ~ o n ~ r e s e a r c h ~ p e r f o r m e d ~}$ by government. These activities include the work of over 150 federal laboratories involving approximately 11,800 scientific or professional staff and 8,600 technicians.

Given these two findings, a central issue in the review process has involved attempting to articulate the role in science and technology that should be played hy government, industry, and the universities. In terms of the government role, there are major concernsthat at least some of the research activities performed hy government have 